\title{
The productivity of boars when introduced to the feed sprouted grains
}

\author{
Aleksandr Kovrigin ${ }^{1 *}$, Grigorii Pokhodnya ${ }^{1}$, Olga Yastrebova $^{1}$, and Yuriy Breslavets ${ }^{1}$ \\ ${ }^{1}$ Belgorod State Agricultural Univerisity named after V.Gorin. vil. Mayskiy, Russia
}

\begin{abstract}
Recipes were developed for compound feeds for boars with replacement of $5 \%$ and $10 \%$ of natural barley grain with sprouted grain. The use of experimental feeds allowed to increase the volume of boar ejaculate-by $25.5 \%$ and $31.9 \%$; sperm concentration-by 18.4 and $20.1 \%$; sperm survival-by 7.7 and 9.2 hours; sperm resistance - by 27.0 and $27.8 \%$. The fertilization rate of sows increased by 3.0 and $6.3 \%$, multiplicity-by 3.1 and $4.2 \%$, large-scale fertility remained at the control level. The cost of compound feed increases with the introduction of sprouted grain, but this increase is economically justified, since the productivity of animals increases. The cost of a dose of sperm from boars is reduced by 2.8 and 3.2 rubles, the number of farrowed sows increases in the experimental groups by 51.8 and $71.4 \%$, respectively, and the cost of one Piglet is lower by $12.4-17.5$ rubles or $8.6-12.6 \%$.
\end{abstract}

\section{Introduction}

For intensive pig farming, it is important to use boars efficiently and increase their reproductive functions. Attempts were made to improve the productive qualities of animals and poultry by various methods: optimizing individual parameters of the microclimate [1], using stimulating drugs and adaptogens, and influencing the sexual sphere with hormonal and other means [2-5]. However, these techniques are not sufficiently implemented in practice due to the high cost of drugs and the complexity of their use in production conditions.in our opinion, it is possible to stimulate the reproductive function of boars much cheaper with feed [6,7].

It is known that sperm production and secretion of the additional sex glands of boars require a large amount of essential amino acids, fatty acids, and other important biological components as a structural material. In addition, studies by a number of authors [8-10] show that each ejaculation of a boar is accompanied by a significant loss of vitamins a, C and others by the body. Therefore, these important components should be included in the compound feed for boars. However, in the conditions of market relations, prices for compound feeds and, especially for high-energy additives, protein and vitamin concentrates, premixes, dry concentrate and other components have sharply increased. Therefore, the method of sprouting grain components can significantly increase their usefulness and at the same time reduce the share of expensive components (premixes).

The use of sprouted grain in compound feeds is a simple, affordable and inexpensive way to increase the vitamin value of diets. In this case, the grain is converted into a dietary feed that exceeds the original one in terms of proteins, essential amino acids, macro-and microelements, vitamins A, C, E, and group B [11].

A number of chemical compounds pass from complex forms to simpler and easily digestible ones. So, starch decomposes to simple Sugars, proteins to amino acids, fats to fatty acids. The amount of soluble nitrogenous compounds increases, and high - energy compoundsphospholipids-are also formed [12].

\section{Materials and Methods}

To study the effectiveness of using sprouted barley grain in the diets of boars-producers, we conducted a scientific and economic experiment at the Gorin collective farm in the Belgorod region, where three groups of Welsh boars aged 2-3 years were selected according to the principle of analogues. The conditions of detention and sexual use for boars of all three groups were the same. During the preparatory period, which lasted 40 days, boars of all experimental groups were fed standard K-57-2 compound feed of $4 \mathrm{~kg}$ per day per head. During the experimental period, the boars of the first control group received the same K-57-2 compound feed, the animals of the experimental groups were fed " experimental compound feed, which included 5 (second) and 10\% (third group) of sprouted barley grain instead of natural.

The boars were fed twice a day according to the VIZ standards, and one head was kept individually in the machine.

The improved formula of compound feeds for boarsproducers, used in scientific and economic experience, is presented in Table 1.

It should be noted that in experimental mixed feeds, in comparison with the standard, the number of feed units and exchange energy decreased by $1.9-2.9$ and $1.7-3.5 \%$,

\footnotetext{
*Corresponding author: : mr.aleks.kovrigin@ mail.ru
} 
respectively. The reason for this is that during the germination of grain, the concentration of dry matter decreases due to the partial loss of organic substances that went to the respiration processes. Therefore, the dry matter content in mixed feeds, which included sprouted barley, decreased by $1.4-3.1 \%$.

The concentration of raw and digestible protein did not change significantly and was at the level of the control variant.

The amount of raw fiber in experimental feed is slightly reduced, but not to such an extent as to focus attention on it. The amount of macronutrients of calcium and phosphorus remained at the same level and did not depend on the feed recipe. The content of some trace elements (iron, copper, zinc and manganese) in the experimental versions of compound feeds decreased insignificantly, while cobalt and iodine increased. When recalculating these mineral substances to absolutely dry feed substance, there is an increase in their compound feed.

Since the method of germination significantly affects the concentration of biologically active substances in the grain, the experimental batches of compound feed showed an increase in vitamins B1, B2 and E: by $1.4-4.5 \%$. The carotene content increased by $0.6-1.2 \%$.

Table 1. Composition and nutrition of compound feeds for boars-producers, $\%$

\begin{tabular}{|c|c|c|c|}
\hline \multirow[t]{4}{*}{ Ingredients } & \multirow[t]{4}{*}{ Control To the $-57-2$} & \multicolumn{2}{|c|}{ Experimental } \\
\hline & & №1 & №2 \\
\hline & & \multicolumn{2}{|c|}{$\%$ input of sprouted grain } \\
\hline & & 5 & 10 \\
\hline Corn & 22,2 & 22,2 & 22,2 \\
\hline Barley & 14 & $9 / 5^{*}$ & $4 / 10^{*}$ \\
\hline Oats & 16 & 16 & 16 \\
\hline Wheat bran & 9 & 9 & 9 \\
\hline Sunflower meal & 17 & 17 & 17 \\
\hline Fish meal & 9 & 9 & 9 \\
\hline Bone meal & 1 & 1 & 1 \\
\hline Herbal flour & 10 & 10 & 10 \\
\hline Desulfurized phosphate & 0,4 & 0,4 & 0,4 \\
\hline Salt & 0,4 & 0,4 & 0,4 \\
\hline Premix P-57-1 & 1 & 1 & 1 \\
\hline \multicolumn{4}{|c|}{$1 \mathrm{~kg}$ contains: } \\
\hline Feed units & 1,05 & 1,03 & 1,02 \\
\hline Exchange energy, MJ & 11,68 & 11,48 & 11,28 \\
\hline Dry matter, $\mathrm{g}$ & 860,0 & 848,0 & 834,0 \\
\hline Digestible protein, $g$ & 188,1 & 187,2 & 186,2 \\
\hline Crude fiber, $g$ & 79,1 & 79,0 & 78,8 \\
\hline Calcium, g & 12,3 & 12,3 & 12,3 \\
\hline Phosphorus, g & 9,9 & 9,9 & 9,9 \\
\hline Iron, $\mathrm{g}$ & 168,2 & 167,0 & 165,8 \\
\hline Crude protein, $g$ & 222,1 & 220,9 & 219,6 \\
\hline Copper, mg & 18,8 & 18,7 & 18,7 \\
\hline Zinc, mg & 72,1 & 71,8 & 71,5 \\
\hline Manganese, mg & 40,2 & 40,1 & 40,0 \\
\hline Cobalt, mg & 1,69 & 1,70 & 1,72 \\
\hline Iodine, mg & 0,67 & 0,77 & 0,89 \\
\hline Carotene, mg & 16,6 & 16,7 & 16,8 \\
\hline Vitamin B1, mg & 4,1 & 4,3 & 4,3 \\
\hline Vitamin B2, mg & 4,2 & 4,3 & 4,4 \\
\hline
\end{tabular}




\section{Results and discussion}

The introduction of sprouted barley grains instead of natural ones into K-57-2 feed increased the sperm production of boars. (Table 2 and Table 3 ).

At $5 \%$ replacement (the second group), the volume of ejaculate increased by $25.5 \%$ compared to the control group, and at $10 \%$ replacement (the third group) - by $31.9 \%$. The concentration of sperm in the second and third groups increased by 18.4 and $20.1 \%$, respectively, compared to the preparatory period.

When comparing the experimental groups of boars with the control variant for this indicator in the experimental period of the experiment, the increase in the concentration of sperm in the second and third groups was, respectively, 44.5 and 50.6 million / $\mathrm{ml}$ (or by 17.5 and $19.9 \%$ ).

The increase in the first two indicators of sperm production (volume and concentration) from feeding the experimental compound feed to boars naturally increased the total number of sperm in the ejaculate. When comparing this indicator between the periods of the experiment, the movement of sperm in the second and third groups was, respectively, 50.0 and $59.8 \%(\mathrm{p}<0.01)$, and in the experimental period the increase in these groups with the control was at the level of 24.39 and 29,90 billion (or 47.4 and 58.2\%).

Having studied the motility of sperm, we found that this indicator was quite high in all groups. At the same time, intergroup differences were insignificant and practically did not depend on the fed compound feed.

Along with motility, an important indicator of the quality of boar sperm is the survival (vitality) of sperm outside the body. As a result of the control over this test, it was found that the survival rate of sperm increases significantly with the use of mixed feed with germinated barley grain in the feeding of boars. With 5 and $10 \%$ introduction of such grain, the survival rate of spermatozoa in the second and third groups increased in comparison with the preparatory period by 7.7 and 9.2 hours, respectively.

Of great importance for the qualitative characteristics of sperm is its indicator - resistance. This test shows the resistance of sperm cells to the action of $1 \%$ sodium chloride solution. This method is based on the action of this salt on the protected lipoprotein membrane of spermatozoa, which protects them from possible harmful effects of the environment. The indicator of resistance is very important, since it is associated with the vitality of sperm, reflects their biological value and fertilizing ability.

In our studies, sperm resistance increased with an increase in the dose of germinated grain in the feed. So, in the second and third groups, this indicator increased, compared with the control variant, by 27.0 and $27.8 \%$, respectively.

Thus, replacing a part of the natural barley grain in the K-57-2 compound feed with germinated ones by 5 and $10 \%$ significantly increased the volume of ejaculate, the total number of sperm and their survival rate. This replacement also contributed to an increase in sperm concentration, motility and sperm resistance. Moreover, the best indicators for sperm production were obtained with a $10 \%$ inclusion of germinated grain. The efficiency of insemination of sows with freshly harvested and frozen semen of experimental boars is presented in Tables 4 and Tables 5.

TABLE 2. Indicators of boar sperm production

\begin{tabular}{|c|c|c|c|}
\hline \multirow{4}{*}{ Indicators } & \multicolumn{3}{|c|}{ Groups } \\
\hline & \multicolumn{3}{|c|}{ preparation period } \\
\hline & I & II & III \\
\hline & \multicolumn{3}{|c|}{ control K-57-2 } \\
\hline $\begin{array}{l}\text { The volume of } \\
\text { ejaculate, } \\
\text { (ML) }\end{array}$ & $\begin{array}{l}201.5 \pm \\
3.85\end{array}$ & $\begin{array}{c}200.0 \pm \\
14.64\end{array}$ & $\begin{array}{l}200.3 \pm \\
3.93\end{array}$ \\
\hline $\begin{array}{c}\text { Concentration } \\
\text { sperm cells, mln / } \\
\mathrm{ml}\end{array}$ & $\begin{array}{c}253.7 \pm \\
27.0\end{array}$ & $\begin{array}{c}252.6 \pm \\
18.0\end{array}$ & $\begin{array}{c}254.0 \pm \\
10.4\end{array}$ \\
\hline $\begin{array}{l}\text { The total number of } \\
\text { spermatozoa in the } \\
\text { ejaculate are, bn }\end{array}$ & $\begin{array}{l}51.12 \pm \\
1.13\end{array}$ & $\begin{array}{c}50.52 \\
\pm 1.31\end{array}$ & $\begin{array}{l}50.88 \pm \\
1.10\end{array}$ \\
\hline $\begin{array}{l}\text { Sperm motility, } \\
\text { points }\end{array}$ & $\begin{array}{l}8.00 \pm \\
0.006\end{array}$ & $\begin{array}{l}7.93 \pm \\
0.006\end{array}$ & $\begin{array}{l}7.96 \pm \\
0.006\end{array}$ \\
\hline Sperm survival, $\mathrm{h}$ & $\begin{array}{l}66.2 \pm \\
1.13 \\
\end{array}$ & $\begin{array}{c}64.8 \pm \\
1.41 \\
\end{array}$ & $\begin{array}{c}65.0 \pm \\
1.20 \\
\end{array}$ \\
\hline Sperm resistance & $\begin{array}{c}950 \pm \\
62.9\end{array}$ & $\begin{array}{l}943 \pm \\
91.3\end{array}$ & $\begin{array}{c}956 \\
\pm 89.6\end{array}$ \\
\hline
\end{tabular}

Table 3. Indicators of boar sperm production

\begin{tabular}{|c|c|c|c|}
\hline \multirow{5}{*}{ Indicators } & \multirow{2}{*}{\multicolumn{3}{|c|}{$\frac{\text { Groups }}{\text { trial period }}$}} \\
\hline & & & \\
\hline & I (K-57-2) & II & III \\
\hline & \multicolumn{3}{|c|}{$\%$ input of germinated grain } \\
\hline & 0 & five & ten \\
\hline $\begin{array}{l}\text { The volume of } \\
\text { ejaculate, } \\
\text { (ML) }\end{array}$ & $\begin{array}{c}202.0 \pm \\
4.31\end{array}$ & $\begin{array}{l}253.5 \pm \\
5.45 * *\end{array}$ & $\begin{array}{l}266.5 \pm \\
6.10 * *\end{array}$ \\
\hline $\begin{array}{l}\text { Concentration } \\
\text { sperm } \\
\text { cells, mln / ml }\end{array}$ & $\begin{array}{c}254.5 \pm \\
13.4\end{array}$ & $299.0 \pm 42.8$ & $\begin{array}{c}305.1 \pm \\
33.0\end{array}$ \\
\hline $\begin{array}{c}\text { The total } \\
\text { number of } \\
\text { spermatozoa } \\
\text { in the } \\
\text { ejaculate are, bn }\end{array}$ & $\begin{array}{c}51.41 \pm \\
1.29\end{array}$ & $\begin{array}{l}75.80 \pm \\
1.88 * *\end{array}$ & $\begin{array}{l}81.31 \pm \\
1.73 * *\end{array}$ \\
\hline $\begin{array}{l}\text { Sperm motility, } \\
\text { points }\end{array}$ & $\begin{array}{l}8.03 \pm \\
0.003\end{array}$ & $\begin{array}{l}8.00 \pm \\
0.003\end{array}$ & $\begin{array}{l}8.06 \pm \\
0.003\end{array}$ \\
\hline $\begin{array}{c}\text { Sperm } \\
\text { survival, h }\end{array}$ & $\begin{array}{c}65.7 \pm \\
0.95\end{array}$ & $\begin{array}{c}72.5 \pm \\
0.75 * * *\end{array}$ & $\begin{array}{c}74.2 \pm \\
1.07 * * *\end{array}$ \\
\hline $\begin{array}{l}\text { Sperm } \\
\text { resistance }\end{array}$ & $968 \pm 90.9$ & $\begin{array}{c}123.1 \pm \\
87.2\end{array}$ & $\begin{array}{c}1237 \pm \\
55.4\end{array}$ \\
\hline
\end{tabular}

Data from Table 6 show that the fertilization rate of sows in the experimental groups increased by 3.0 and $6.3 \%$, multiplicity-by 3.1 and $4.2 \%$, and large-scale fertility remained at the level of the control variant.

When using frozen sperm for insemination of sows, there is a tendency to increase in comparison with the control of the above-mentioned indicators, except for large-fruiting (Table 6,7). Thus, the fertilization rate of Queens increased by 6.6 and $10.0 \%$, and multiple pregnancies-by 7.2 and $8.0 \%$. Large-fruited remained at the control level. 
Data from Table 8 show that with the same consumption of compound feed, its cost in the second and third groups was higher compared to the control by 12.4 and 24.8 rubles. However, this difference was completely covered by receiving additional spermodoses from boars of the second and third groups due to an increase in the volume of ejaculate and the concentration of sperm in it. The cost spermatozoa decreased in comparison with control PA 2,8 and 3,2 RUB.

Using this sperm to inseminate sows also had a positive effect. The number of farrowed sows increased in the experimental groups by 51.8 and $71.4 \%$, respectively. The above mentioned caused an increase in the cost of maintaining sows and piglets in the experimental groups, but the cost of one pig became lower than PA .12, 4-17.5 rubles or $8.6-12.6 \%$. At the same time, it is more costeffective to use compound feed for boars with a $10 \%$ inclusion of sprouted barley. This feeding allows producers to improve quantitative and qualitative characteristics of sperm, increase the number of sperm doses and reproductive qualities of sows from using semen of Guinea pig boars for insemination. The effectiveness of the use of experimental compound feed for boars is reflected in Table 8

Table 4. Reproductive functions of sows when they are inseminated with fresh sperm

\begin{tabular}{|c|c|c|c|}
\hline \multirow{2}{*}{ Indicators } & \multicolumn{3}{|c|}{ Groups } \\
\cline { 2 - 4 } & \multicolumn{3}{|c|}{ preparation period } \\
\cline { 2 - 4 } & I & II & III \\
\cline { 2 - 4 } & \multicolumn{3}{|c|}{ control K-57-2 } \\
\hline Sows inseminated & thirty & thirty & thirty \\
\hline of them farrowed & 25 & 24 & 24 \\
\hline in \% & 83.3 & 80.0 & 80.0 \\
\hline Plurality, heads & $9.52 \pm$ & $9.50 \pm$ & $9.60 \pm$ \\
& 0.2 & 0.2 & 0.2 \\
\hline \multirow{2}{*}{ Large-fruited, $\mathrm{kg}$} & $1.22 \pm$ & $1.25 \pm$ & $1.21 \pm$ \\
& 0.01 & 0.01 & 0.02 \\
\hline
\end{tabular}

Table 5. Reproductive Functions Of Sows When They Are Inseminated With Fresh Sperm.

\begin{tabular}{|c|c|c|c|}
\hline \multirow{2}{*}{} & \multicolumn{3}{|c|}{ Groups } \\
\cline { 2 - 4 } & \multicolumn{3}{|c|}{ preparation period } \\
\cline { 2 - 4 } & $\mathrm{I}(\mathrm{K}-57-2)$ & $\mathrm{II}$ & III \\
\cline { 2 - 4 } & \multicolumn{3}{|c|}{$\%$ input of germinated grain } \\
\cline { 2 - 4 } & 0 & five & ten \\
\hline Sows inseminated & 50 & 60 & 60 \\
\hline of them farrowed & 41 & 51 & 53 \\
\hline in \% & 82.0 & 85.0 & 88.3 \\
\hline \multirow{2}{*}{ Plurality, heads } & $9.60 \pm$ & 10.0 & $9.90 \pm$ \\
& 0.1 & $\begin{array}{c} \pm \\
0.2\end{array}$ & 0.1 \\
\hline Large-fruited, $\mathrm{kg}$ & $1.25 \pm$ & $\begin{array}{c}1.23 \\
\pm\end{array}$ & $1.24 \pm$ \\
& 0.01 & 0.02 & 0.01 \\
\hline
\end{tabular}

Table 6. Reproductive functions of sows during insemination with frozen sperm

\begin{tabular}{|c|c|c|c|}
\hline \multirow{2}{*}{ Indicators } & \multicolumn{3}{|c|}{ Groups } \\
\cline { 2 - 4 } & \multicolumn{3}{|c|}{ preparation period } \\
\cline { 2 - 4 } & I & II & III \\
\cline { 2 - 4 } & \multicolumn{3}{|c|}{ control K-57-2 } \\
\hline Sows inseminated & thirty & thirty & thirty \\
\hline of them farrowed & nineteen & 20 & 20 \\
\hline in \% & 63.3 & 66.7 & 66.7 \\
\hline Plurality, heads & 8.72 & 8.83 & 8.79 \\
\hline Large-fruited, kg & 1.35 & 1.34 & 1.35 \\
\hline
\end{tabular}

Table 7. Reproductive functions of sows during insemination with frozen sperm

\begin{tabular}{|c|c|c|c|}
\hline \multirow{2}{*}{} & \multicolumn{3}{|c|}{ Groups } \\
\cline { 2 - 4 } & \multicolumn{3}{|c|}{ trial period } \\
\cline { 2 - 4 } Indicators & $\begin{array}{c}\text { I (K- } \\
57-2)\end{array}$ & II & III \\
\cline { 2 - 4 } & $\%$ input of germinated grain \\
\cline { 2 - 4 } & 0 & five & ten \\
\hline Sows inseminated & thirty & thirty & thirty \\
\hline of them farrowed & 20 & 22 & 23 \\
\hline in \% & 66.7 & 73.3 & 76.7 \\
\hline Plurality, heads & 8.80 & 9.50 & 9.43 \\
\hline Large-fruited, kg & 1.37 & 1.35 & 1.36 \\
\hline
\end{tabular}

Table 8. The effectiveness of the use of experimental compound feeds in the diets of boars (per head for the experimental period)

\begin{tabular}{|c|c|c|c|}
\hline Indicators & \multicolumn{3}{|c|}{ Groups } \\
\cline { 2 - 4 } & I & II & III \\
\hline $\begin{array}{c}\text { Combined feed } \\
\text { consumed, c }\end{array}$ & 2.48 & 2.48 & 2.48 \\
\hline $\begin{array}{c}\text { The cost of the consumed } \\
\text { compound feed, rub. }\end{array}$ & 744.0 & 756.4 & 768.8 \\
\hline $\begin{array}{c}\text { Boar maintenance costs, } \\
\text { rub. }\end{array}$ & 1240.0 & 1252.4 & 1264.8 \\
\hline Sperm dose received & 138 & 202 & 218 \\
\hline Sperm dose cost, rub. & 9.0 & 6.2 & 5.8 \\
\hline Sows inseminated & 69 & 101 & 109 \\
\hline Of them farrowed, goal. & 56 & 85 & 96 \\
\hline $\begin{array}{c}\text { Multiple pregnancy, } \\
\text { goal. }\end{array}$ & 9.6 & 10.0 & 9.9 \\
\hline Received piglets, goal & 537 & 850 & 950 \\
\hline $\begin{array}{c}\text { Costs for the } \\
\text { maintenance of sows for } \\
120 \text { days. rub. }\end{array}$ & 82800 & 121200 & 130800 \\
\hline $\begin{array}{c}\text { Total costs for piglets } \\
\text { received, rubles }\end{array}$ & 84042.0 & 122454, & 132064.4 \\
\hline $\begin{array}{c}\text { Cost of one pig at birth, } \\
\text { rub. }\end{array}$ & 156.5 & 144.1 & 139.0 \\
\hline $\begin{array}{c}\text { Difference with } \\
\text { control, rub. }\end{array}$ & - & -12.4 & -17.5 \\
\hline
\end{tabular}




\section{Conclusion}

The introduction of sprouted grain in the diets of boars in the amount of 5 and $10 \%$ by weight showed a positive effect on their productivity. Thus, the volume of ejaculate increased by $25.5 \%$ compared to the control group, and at $10 \%$ - POI (the third group) - by $31.9 \%$. The concentration of sperm in the second and third groups increased by 18.4 and $20.1 \%$, respectively, compared to the preparatory period. The survival rate of spermatozoa in the second and third groups increased by 7.7 and 9.2 hours, respectively, in comparison with the preparatory period. Sperm resistance in the second and third groups increased by 27.0 and $27.8 \%$, respectively, compared to the control variant.

The fertilization rate of sows in the experimental groups increased by 3.0 and $6.3 \%$, multiplicity-by 3.1 and $4.2 \%$, large-scale fertility remained at the level of the control variant.

The cost of compound feed increases with the introduction of sprouted grain, but this increase is justified, since the productivity of animals increases. The cost of a dose of sperm from boars is reduced by 2.8 and 3.2 rubles, the number of farrowed sows increases in the experimental groups by 51.8 and $71.4 \%$, respectively, and the cost of one Piglet is lower by $12.4-17.5$ rubles or 8.6 - $12.6 \%$. Thus, the introduction of sprouted barley grain in the amount of $5 \%$ and $10 \%$ in the diet of boars is economically justified.

\section{References}

1. S.A. Eriomin, and O.N. Durykhina, "The use of computers to control the microclimate in poultry farms," Proceedings of the International student scientific conference, Belgorod: Publishing house of BelSAU, pp.80-81, April 2008.

2. G.S. Pokhodnya, A.V. Kovrigin, and A.M. Mamenko "Innovative technologies of using the unconventional feed in the production of agricultural products," Problems of Zooengineering and Veterinary Medicine, Kharkiv, no. 31-1, pp.164166, 2015.

3. N.N. Shvetsov, G.S. Pokhodnya, and S.P. Salamakhin "New feeds with extruded grains," Stock Farming of Russia, no. 10, pp. 43-44, 2009.
4. O.N. Yastrebova, Feeding of farm animals: Textbook for students of SVE specialty 36.02.02 Animal Science, Belgorod: Belgorod SAU, 2016.

5. V.A. Panarina, and O.N. Yastrebova, "Cultivation of fish and plants with aquaponic technology," Gorin readings. Science of young - for innovative development of agriculture. Materials of the international student scientific conference, Belgorod: Belgorod SAU, pp. 126-127, 2019.

6. A.V. Kovrigin, "Automated technology of manufacture of ecologically clean products in crop production and aquaculture in controlled conditions of premises," Innovations in Agricultural Complex: Problems and Perspectives, Belgorod: Belgorod SAU, no. 4 (12), pp. 124-129, 2016.

7. A.V. Kovrigin, A.P. Khokhlova, and N.A. Maslova "Study of the efficiency of operation of an automated aquaponic installation depending on the modes of its operation," Bulletin of KrasGAU, pp. 90-96, no. 11, 2015.

8. A.V. Kovrigin, Applied computer programs in breeding and feeding. Textbook, public house of Belgorod SAU, 2010.

9. A.V. Kovrigin, "Some aspects of the development of innovative technologies of pork production in medium and small agricultural enterprises of Russia," Collection of scientific works of the scientific school of professor G.S. Pokhodnya, Issue no. 4, Belgorod: publishing house of BelSAU, pp. 48-49, 2011.

10. G.S. Pokhodnya, E.G. Fedorchuk, A.I. Grishin, and R.A. Strelnikov "Suspension of chlorella in rations of sows," Vestnik of Kursk State Agricultural Academy. Kursk: Public house of Kursk State Agricultural Academy, no. 4, pp. 47-48, 2012.

11. G.S. Pokhodnya, P.P. Kornienko, and A.V. Kovrigin, Increase of the reproductive capacity of pigs. Belgorod: Public house of Belgorod SAU, 2013.

G.S. Pokhodnya, N.I. Bogdanov, E.G. Fedorchuk, A.I Grishin., N.P. Dudina, and Yu.P. Breslavets, Recommendations for the use of chlorella suspension in the diets of pigs. Belgorod, 2012 